\title{
A COLLECTION OF ABSTRACTS OF RECENT DOCTORAL RESEARCH ON THE BAHAMAS
}

Compiled by

Berthamae Walker, M.L.S.

Deputy Director,

Library and Instructional Media Services

https://doi.org/10.15362/ijbs.v13i0.64 


\title{
THE INTERROGATION OF HISTORY IN WEST INDIAN WOMEN'S NARRATIVE: ERNA BRODBER AND JAMAICA KINCAID
}

\author{
Michelene Adams (Ph.D., Literature) \\ University of New Brunswick, 2004
}

The most prominent voices in the discourse on history in the West Indies have traditionally been male-- Wilson Harris, George Lamming, Derek Walcott, Edward Kamau Brathwaite. However, what this thesis seeks to establish is that although women writers were virtually unheard in the discourse until the 1960s, since then their sexual and gender differences and their particular social experiences as females have impelled them to address history in fresh ways, encouraging a consistent interrogation of history.

Chapter One provides the necessary context regarding the development of the region's historiography and its historical fiction. It also explains the dearth of women's writing up to the 1960s, addresses the misrepresentation of females in men's writing, and discusses the first major historical novels by women. Chapter Two examines narratives by Jamaican Erna Brodber, and Chapter Three focuses on Antiguan Jamaica Kincaid. Feminist and postcolonial ideas frame these studies, although Brodber's texts also require that various strands of black theory be applied because she imbricates West Indian history with black history generally.

The intricate structures of Brodber's texts are highlighted because they challenge the standard constructs of race, gender, and even time. As well, they substantiate the links between blacks. The linguistic make-up of the works is analysed to reveal a multivocality that reflects the composite nature of West Indian society. Brodber's incorporation of black myths, folklore, and other folk forms is explored and establishes the depth and breadth of her vision.

The thesis also analyses Kincaid's decolonising fictions and demonstrates that they are especially effective because she finds singular ways of appropriating and manipulating the language and the narrative forms of the West to create them. It explores how Kincaid challenges traditional histories by inverting and subverting the codes of master texts, all the while emphasising women's experience.

Ultimately, the thesis establishes that in redefining history, women writers have called the accepted notions of gender, race, culture, and power into question, and in some instances, have even encouraged West Indians to imagine a more genuine and whole identity. 


\section{BAHAMIAN WOMAN SPEAK: THE CARIBBEAN CONNECTION}

Marjorie Brooks-Jones (Ph.D., Literature)

University of Miami, 2004

Miami, Florida

This dissertation seeks to contribute to the scholarship on Bahamian literature generally and Bahamian women's literature in particular. The study provides as a meaningful context for the critical evaluation of Bahamian women's literature, the cultural specificity of Anglophone Caribbean literature to which it bears close relation.

The dissertation contends that Bahamian women's literature is not a body of literature separate or disjunct from Caribbean literature. It posits the inclusion of Bahamian women's literature in Caribbean women's literary space through first delineating correspondences of historical experience represented in non-fictional and fictional texts.

It examines the mythologizing and demythologizing texts of colonial women in The Bahamas and the larger Caribbean. It reads texts by Mary and Henrietta Kelsall, Mary Seacole, and Mary Prince. Subsequently, through a nexus of postcolonial, feminist, and gender theories the study demonstrates the mutuality of thematic issues and interrogations in contemporary women's writings of the Anglophone Caribbean and The Bahamas.

It focuses on their representation of modernity's problematic legacies, specifically modernist categories of identity such as gender, sex and nation. Although it acknowledges differences, the dissertation makes clear the linkages between Caribbean women writers represented by Jamaica Kincaid and Michelle Cliff, and their Bahamian counterparts, Marion Bethel, Susan Wallace, Telcine Turner and Patricia Glinton-Meicholas. It emphasizes their shared intellectual interests. It re-members Bahamian women's literature in the Caribbean literary space. 


\section{DEVELOPMENT OF A PLAN FOR THE IMPLEMENTATION AND EVALUATION OF PROGRAMS TO MEET THE EDUCATIONAL NEEDS OF ADULTS ON ANDROS ISLAND, BAHAMAS}

by Christina A. Rahming Nwosa, Ed.D.

Nova Southeastern University, 2004

Development of a Plan for the Implementation and Evaluation of Programs to Meet the Educational Needs of Adults on Andros Island, Bahamas. Rahming Nwosa, Christina A., 2004: Applied Dissertation, Nova Southeastern University, Fischler Graduate School of Education and Human Services. Adult Education/ Adult Education Programs/Educational Needs/Program Implementation/ Program Evaluation.

There exists a paucity of opportunities for adults on the Family Islands of The Bahamas to obtain higher education, as there is minimal infrastructure on these islands to support the traditional face-to-face mode of educational delivery at the tertiary level. This project was designed to develop a plan for the implementation and evaluation of programs to meet the educational needs of adults on Andros Island, Bahamas. The plan that was developed utilized 14 procedures to answer 4 research questions. The 4 research

questions addressed were (a) What are the educational needs of adults on Andros Island?, (b) Currently, what is the best practice for educational delivery taking into consideration the demographics of the population and the geographical location of Andros Island?, (c) What elements (criteria and components) should be included in a plan for the implementation of programs to meet identified needs?, and (d) What elements (criteria and components) should be included in the plan for an evaluation of the program that will meet identified needs?

The nonexperimental research methodology was the primary problem-solving approach used to survey the population in an effort to ascertain their educational needs. The evaluation and developmental methodologies were also utilized to develop the survey tool and the subsequent plan.

The survey response rate was $72 \%(\mathrm{~N}=144)$. The results of the study indicated that $75 \%$ of respondents were educated up to the secondary level. They also revealed that $83 \%$ of respondents indicated that they would register in courses if they were offered via distance. The results also showed that $87 \%$ of the respondents could use the computer and $72 \%$ of them could access the Internet.

From this study, it was concluded that there exists a great need for college preparatory programs on the Family Islands, particularly on Andros Island. It was also discovered that technology exists on Andros Island to support the distance mode of educational delivery.

This study recommends that the plan that was developed be implemented within 4 to 6 months of the approval of this applied dissertation. It is also recommended that The College of The Bahamas adapt courses from the Certificate in Business Administration so that they could be offered via distance. It is further recommended that future research should be undertaken to examine the impact that this plan has had on the communities of Andros Island in The Bahamas. 